\title{
Plotinus' Legacy: The Transformation of Platonism from the Renaissance to the Modern Era, dir. S. GERSH
}

\section{Gianmario Cattaneo}

\section{OpenEdition}

\section{Journals}

\section{Edizione digitale}

URL: https://journals.openedition.org/studifrancesi/31513

DOI: 10.4000/studifrancesi.31513

ISSN: 2427-5856

\section{Editore}

Rosenberg \& Sellier

\section{Edizione cartacea}

Data di pubblicazione: 1 août 2020

Paginazione: 389

ISSN: 0039-2944

\section{Notizia bibliografica digitale}

Gianmario Cattaneo, «Plotinus' Legacy: The Transformation of Platonism from the Renaissance to the Modern Era, dir. S. Gersh», Studi Francesi [Online], 191 (LXIV | II) | 2020, online dal 01 septembre 2020, consultato il 18 septembre 2021. URL: http://journals.openedition.org/studifrancesi/31513 ; DOI: https://doi.org/10.4000/studifrancesi.31513

Questo documento è stato generato automaticamente il 18 septembre 2021.

\section{(c) $($ ) $(9)$}

Studi Francesi è distribuita con Licenza Creative Commons Attribuzione - Non commerciale - Non opere derivate 4.0 Internazionale. 


\title{
Plotinus' Legacy: The Transformation of Platonism from the Renaissance to the Modern Era, dir. S. GERSH
}

\author{
Gianmario Cattaneo
}

\section{NOTIZIA}

Plotinus' Legacy: The Transformation of Platonism from the Renaissance to the Modern Era, dir.

S. GERSH, Cambridge, Cambridge University Press, 2019, 304 pp.

1 La raccolta di studi Plotinus' Legacy: The Transformation of Platonism from the Renaissance to the Modern Era ospita due saggi dedicati a tre importanti filosofi francesi del Cinquecento, ovvero Jacques Lefèvre d'Étaples, Charles de Bovelles e Symphorien Champier.

Il contributo di Richard J. oosterhoff si intitola Jacques Lefêvre d'Étaples and Charles de Bovelles on Platonism, Theurgy, and Intellectual Difficulty (pp. 78-95). Dopo aver tratteggiato brevemente la loro carriera, Oosterhoff si concentra sul modo in cui il pensiero di Plotino fu recepito dai due intellettuali, i quali, dopo gli studi condotti in Italia, divennero insegnanti al Collège du Cardinal-Lemoine di Parigi. Per quanto riguarda Lefèvre d'Étaples, egli da una parte consigliava agli studenti la lettura dell'Introduzione alle Categorie aristoteliche di Porfirio, allievo di Plotino; dall'altra, egli contestava apertamente i punti di questo trattato in cui emergeva maggiormente il neoplatonismo del suo autore. Tuttavia, sia Lefèvre d'Étaples sia Bovelles fecero propri alcuni spunti provenienti dalla filosofia plotiniana attraverso altre fonti, come i trattati dello pseudo Dionigi l'Areopagita. Partendo da queste premesse, Oosterhof si concentra in particolare su una tematica, ovvero il modo in cui l'uomo può raggiungere la vera sapienza secondo Plotino e i due filosofi francesi. L'autore conclude dicendo: «neither Lefèvre nor Bovelles saw themselves as heirs of Plotinus, even as they drew on him» (p. 92). 
3 In Symphorien Champier on Medicine, Theology, and Politics (pp. 96-123) Guido GIGLIONI analizza la presenza della filosofia plotiniana all'interno delle riflessioni di Symphorien Champier sul rapporto tra medicina e filosofia. Giglioni mostra come l'interpretazione di Plotino da parte di Champier sia fortemente influenzata dai lavori di Marsilio Ficino sulle Enneadi e afferma: «His main contribution in embedding Plotinus' philosophy in Renaissance culture lay in popularising and making accessible to a wider public certain aspects of Plotinian metaphysics. This occurred especially in three areas: the Christianisation of Plotinus' philosophy [...]; the emerging of a more robust sense of the individual self; and, finally, the attempt to free a set of characteristically late Platonic notions [...] from their most troublesome implications of magic and theurgic rituals» (p. 96). 